\title{
Prescripciones legales sobre la solución de controversias judiciales en los países miembros de BRICS
}

\author{
Legal requirements on the settlement of judicial disputes in the \\ BRICS countries \\ Ksenia Michailovna Belikova ${ }^{1 \mathrm{a}}$ \\ Peoples' Friendship University of Russia (RUDN University), Moscow, Russia1 \\ Orcid ID: https://orcid.org/0000-0001-8068-1616 ${ }^{1}$
}

Recibido: 03 de julio de 2020

Aceptado: 07 de octubre de 2020

\begin{abstract}
Resumen
Este artículo tiene como objetivo esbozar los enfoques para la solución de controversias previas al juicio en el establecimiento y desarrollo de la resolución alternativa de controversias (ADR) en los países BRICS (Brasil, Rusia, India, China y Sudáfrica) en forma de solución voluntaria con énfasis en la construcción de un sistema de procedimientos alternativos. En este contexto, este estudio brinda una comprensión del vector de desarrollo del ADR en el formato de los BRICS, basado en una legislación relativamente nueva, que no ha reflejado adecuadamente en fuentes académicas. A partir de reflexiones analíticas sobre información obtenida de fuentes y literatura señaladas en las referencias, el artículo analiza las disposiciones de los actos y documentos normativos de los países BRICS, creando patrones de desarrollo de ADR y el potencial para su uso desde la posición de principios legales. Los resultados se presentan en un conjunto de prescripciones legales y disposiciones científicas dentro de la legislación vigente respecto al campo de la investigación.
\end{abstract}

Palabras clave: juicio, tribunal, BRICS, disputa legal.

\begin{abstract}
This article aims to outline approaches to pre-trial dispute resolution in the establishment and development of Alternative Dispute Resolution (ADR) in BRICS countries (Brazil, Russia, India, China, and South Africa) in the form of voluntary settlement. with emphasis on building a system of alternative procedures. In this context, this study provides an understanding of the development vector of ADR in the BRICS format, based on relatively new legislation, which has not been adequately reflected in academic sources. Based on analytical reflections on information obtained from sources and literature indicated in the references, the article analyzes the provisions of the acts and normative documents of the BRICS countries, creating patterns of ADR development and the potential for its use from the position of principles legal. The results are presented in a set of legal prescriptions and scientific provisions within the current legislation regarding the field of research.
\end{abstract}

Keywords: trial, court, BRICS, legal dispute. 


\section{Introduction}

The irreversible process of globalization is changing the usual practice of cooperation from trade relations inside the countries to expanding international trade relations in the privatesector. Business, trade and economic cooperation between Russia and other countries associated to BRICS is developing rapidly. The successful functioning of the system of business relations that are unfolding in this way requires new conditions, one of which is the operational resolution of emerging issues, including the rapid and at the same time high-quality settlement of arising disputes. In this regard, in many countries of the world, efforts have been undertaken in the alternative dispute resolution methods: they are less conservative, more flexible with regard to the formal procedure and the final decision making (Nosyreva, 2007; Poole 2011).

Since such methods of dispute settlement, comprising the toolkits used by various world arbitration institutions and institutions offering dispute resolution, are not alien to the BRICS countries, the author aims to outline the approaches of the mentioned countries to the pre-trial (quasi-judicial) dispute settlement and landmarks of alternative dispute resolution (ADR) establishment and development in the BRICS countries as voluntary pre-trial dispute settlement with an emphasis on constructing an alternative procedures system (Kaufmann-Kohler, Fan, 2008; Belikova, 2015).

From the viewpoint of approaches to achieving this goal, we proceed from a look at the subject of research from the perspective of the advantages provided by the mechanism of pretrial dispute settlement in the BRICS nations over other methods of dispute resolution. The novelty of the present study in this format is determined by an integrated approach to achieving the goal, both from the perspective of national legal sources of the BRICS countries chosen by the author for the research, and the very goal of identifying the approaches to regulating these relations and the landmarks of the ADR formation and development therein (Dutta, 2015).

\section{Literary review}

In some academic sources (Bannikov, 2012) pre-trial dispute settlement is designated, for example, as a mandatory non-judicial procedure, which is established by federal law or by agreement of the parties, compliance with which is a prerequisite for the exercise of the right to sue, as well as subsequent consideration and resolution of the dispute by the court. This approach was valid in the Russian Federation (RF) until 1995, when the pre-trial dispute settlement was mandatory, for example, according to the 1992 APC of the Russian Federation (1992).

In the new codes (Civil Procedural Code [CPC] and Arbitration Procedural Code [APC]) of the Russian Federation of 2002, it was abandoned, except for some situations established by law, for example, disputes with a railway carrier, etc. Thus, according to paragraph 2, Part 1, Article 148 of the APC RF (2002) the arbitration court leaves the claim without consideration 

provided, after its acceptance by court, it establishes that the plaintiff did not comply with the pre-trial procedure for settling the dispute with the defendant, if required by federal law or contract. The same is envisaged in the 2002 CPC of the Russian Federation (2002): the court leaves the claim without consideration if the plaintiff has not complied with the pre-trial procedure established by the federal law for this category of cases or the dispute settlement procedure stipulated by the parties' agreement (Article 222 of the CPC of the RF; Somoy, 2004).

Thus, pre-trial, preliminary, or so-called "complaining" pre-trial dispute settlement, is mandatory per se in some cases when one party presents a complaint to the other party. In fact, one party, dissatisfied with the performance of a contract by the other party, writes a complaint thereto, and the latter must respond. Such a request and response procedure are a complaint procedure, or written negotiations. Unless this procedure is followed, that is, the parties failed to comply with the requirements of the law regarding pre-trial dispute settlement, the court does not consider the claim.

Similarly, the pre-trial settlement procedure, for example, for tax disputes in domestic scientific books, articles, etc., is defined as "a procedure that allows taxpayers and tax authorities to find out the contradictions and disagreements at the first stage of their occurrence in the period after completion of the tax audit or in the period after detection of a tax offense, without going directly to the arbitration court" (Chernik, 2012; Baistrocchi, 2012). In some cases, this order is mandatory. For example, in accordance with paragraph 1, Article 104 of the Tax Code of the Russian Federation (1998) prior to filing a lawsuit the tax authority is obliged to offer the taxpayer (other person) to voluntarily pay the amount of the tax sanction, by sending a claim or other document to all known taxpayer's (other person's) addresses. Otherwise, the goal set by the legislator will not be achieved - the possibility of resolving the dispute on the imposition of the tax sanction without filing a lawsuit. If the tax authority fails to fulfill its duty, then in a subsequent trial this will give the court grounds to refuse the tax authority to consider the claim. This procedure performs four main functions: 1) determines the existence of a dispute; 2) concentrates court proceedings; 3) allows for dispute resolution; 4) makes it possible to minimize the costs of the parties.

In the absence of binding legal provisions making the parties claim pre-trial settlement of disputes, the parties themselves resort to negotiations within the framework of a voluntary procedure without any coercion, based on common sense. The parties can stipulate the need for a preliminary pre-trial procedure into the terms of the contract, according to which no one shall apply to court until the possibilities of the negotiation process are used. If the contract contains the wording that all disagreements of the parties before filing a lawsuit should be resolved through negotiations, this procedure is voluntary for the parties, and mandatory for the court 
(2004). Such non-judicial (out-of-court, alternative) dispute settlement is applied in civil law, labor, tax and many other legal relationships.

The system of alternative procedures is classified on various grounds. For example, they are divided into two groups. The first group includes conciliation and reconcilement procedures. The latter can be carried out with the participation of third neutral persons (i.e. mediation) or without third persons (i.e. negotiations). In this classification, the second group includes International Commercial Arbitration (ICA). The difference in arbitration procedure from nonjudicial forms and its similarity to the procedure for considering disputes in courts is the reason for classifying it as a separate group. For the same reason, ICA in the ADR system occupies a special place (Nosyreva, 2007). Or three groups of procedures are identified (Riskin and Westbrook, 1987): adversary procedures (judicial process, administrative process, arbitration); consensual procedures (negotiations, mediation, reconciliation, Ombudsman, independent expert examination to establish the circumstances of the case); mixed procedures (mediationarbitration, mini-court). Traditionally, all alternative forms of resolving legal conflicts are divided into basic (arbitration, mediation) and combined (med-arb, Ombudsman, "mini-court", etc.). Often the following procedures are referred to the basic forms: 1) reconciliation of the parties without third parties (i.e. negotiations); 2) mediation - with an independent and neutral intermediary involved; 3) arbitration court (arbitration) - with the help of an independent and neutral person - an arbitrator (or group of arbitrators) authorized to make a decision binding on the parties (Davis and Netzley, 2001).

An out-of-court dispute settlement procedures may also include administrative proceedings (arbitration) in the form of a quasi-judicial procedure (adjudication; BarnardNaude, 2012). The status of such institutions in dispute resolution is a characteristic feature that distinguishes them from the courts. If the court conducts the proceedings between the parties (including with the participation of a state authority) as an arbitrator, administrative institutions themselves are a party to the applications (claims) of individuals. Being judex in propria causa, such institutions have formed a special system of bodies of administrative justice (Kozyrin, 1996). Contestation of acts of administration is possible by administrative claims that are considered by the bodies and services of the active administration system (for example, appeals divisions of various ministries). They do not have jurisdictional functions and use internal investigation and consideration procedures in their work. In many countries, these departments are specialized, separated from the active administration and vested with the right to use separate judicial procedural rules for the consideration of claims, which leads to their transformation into quasi-judicial bodies (Zelentsov, 1997). Since decisions of such bodies can almost always be appealed in courts, the administrative (quasi-judicial) procedure for the dispute settlement can be attributed simultaneously to the pre-trial dispute settlement, with a degree of conditionality. Therefore, this article discusses the main provisions of the legislation 

and quasi-judicial dispute settlement, applied for certain legal relations.

\section{Methodology}

This study was carried out on the basis of expert data contained in the publications of Russian and foreign researchers engaged in a selected range of issues, based on the fact that the ADR method under consideration has several advantages over other methods. These are Riskin and Westbrook (1987), who devoted their research to the issue of correlation of out-of-court and judicial dispute settlement methods; Bannikov (2012), Somov (2004), Nosyreva (2007), Davis and Netzley (2001) regarding general ADR issues; T. Chandra (2019), Chernik (2012), concerning ADR in tax, land and other disputes, including from the standpoint of their activities as "quasi-judicial" bodies, for example, Barnard-Naude (2012), Kozyrin (1996), and Zelentsov (1997); and in the regional geographic aspect, for example, Engelmann (2015) and Poole (2011) in Brazil, Tikhomirov (2001) and others in Russia; Dhavan (2013), Dutta (2015), Relyea, and Bhatt (2009) in India; Kaufmann-Kohler, and Fan (2008) and Young and Zhu (2012) in China; Ampeire (2017) in South Africa; and Belikova (2012) covering all BRICS countries. These publications emphasize the different facets of competition and approaches to legal regulation thereof and the perception of corresponding changes by market participants, anti-monopoly authorities, the state, etc., they lack compre

Thus, the method of systematic analysis and reflection on the ideas provided in the aforementioned articles, book chapters, etc., along with such operations as induction and deduction, is used while considering the provisions of BRICS countries' legislation in the field under study. The methods of formal and dialectical logic help understand the relationship between the needs of the parties to the dispute and regulatory settlement thereof; the materialistic view of the processes and phenomena of the external world as a whole make the study proceed from the fact that judicial dispute settlement is sometimes insufficient to balance the interests of the parties and achieve a favorable effect from protection by the rule of law.

\section{Results}

1. It is established that the legislation of the BRICS countries provides for pre-trial settlement of a dispute by both its parties and interested third parties (trusted or legal representatives) in the form of negotiation or conciliation processes.

2. It is shown that the laws of India and China allow the participation in such procedures of an independent third party - professional mediators while in other BRICS countries the use of mediation is practically not developed and is not legally fixed, although in national doctrines this procedure is recognized as an effective method. 
3. It has been found that the laws of India and China allow a judge to suspend proceedings at any stage and refer disputes for alternative settlement either to arbitration, or to independent professional mediators in India or another judge in China, or to People's mediators in China or to a Court ("Lok Adalat") in India.

\section{Discussion}

This study aims to define the approaches of the BRICS to the pre-trial (quasi-judicial) dispute settlement and to identify the milestones in the formation and development of the alternative dispute resolution as voluntary pre-trial dispute settlement with an emphasis on constructing alternative procedures. In Brazil, for many years, the issue of the judicial system reformation has been on the agenda, including solving the problem of the effectiveness of the judicial bodies and overcoming the crisis of public trust in national courts (Engelmann, 2015). Often the high cost of trial is an obstacle to the access to justice for some Brazilian citizens. Whereas mediation, as an alternative to trial, requires, as experts steadily presume, much lower costs, and, moreover, agreement of the parties is reached faster than a decision is made in the process of court trial. In this regard, the need to introduce alternative, including pre-trial, methods for resolving civil and commercial disputes and enshrining the corresponding institutions at the statutory level is undeniable.

In case of a decision to conduct a conciliation procedure, the parties to the dispute hold joint negotiations, during which they can come to a common opinion that judicial recourse in their situation is not the best way to resolve the conflict. However, the decision-making process during negotiations is very complicated because of the lack of neutrality of the parties and the confidentiality of the procedure. Therefore, according to Brazilian researchers (Poole, 2011), the legislation of their country still needs to establish an institution of a neutral person to resolve the dispute.

In Russian legal theory and practice, the stable phrase "alternative dispute resolution" and its abbreviation "ADR" firmly entered into circulation. The intensive pace of development of ADR methods and mechanisms in our country is caused by the fact that they often turn out to be more effective and efficient than traditional methods. However, currently, the number of the most common forms of alternative, including pre-trial, dispute settlement in Russia includes negotiations, arbitration (arbitration), and mediation.

From a legal point of view, the definition of "negotiations" as an effective method to prevent and resolve legal conflicts, as a process by which the parties involved in a legal conflict discuss reaching a mutually acceptable agreement is more accurate (Tikhomirov, 2001). In this case, "the Russian negotiation mentality is a very strong approach, and a rather inflexible one, which to some extent ignores emotional and psychological considerations often discussed in negotiation theory" (Hkust \& Skolkovo, 2020). At the same time, the only definition that 
remains common is the goal of resorting to this method of alternative dispute resolution: to reach a compromise solution that would suit the parties concerned and all participants involved in the dispute.

India's interest in developing alternative dispute settlement mechanisms in the country at the present stage is conditioned by several reasons. In cases where, in the court's opinion, there are grounds for resolving a dispute between the parties in an alternative manner, the court must set out in writing the conditions for the dispute resolution and submit them to the parties for consideration; the court can reformulate the conditions set forth earlier and determine the following methods for resolving a dispute between the parties: 1) conciliation proceedings; 2) arbitration trial; 3) Lok Adalat (an Indian alternative dispute resolution) proceedings; and 4) mediation. When resolving a dispute between the parties by the first two methods, the Arbitration and Conciliation Act of 1996 is applied (Relyea and Bhatt, 2009). The Lok Adalat system was introduced for the first time at the legislative level by the Legal Service Authorities Act, 1987 (2002), which entered into force in 1989 with the purpose of implementing programs to provide qualified free legal assistance to poorly protected segments of the population.

As a rule, Lok Adalat consists of three authoritative people - former judges and junior members of the court - mainly of its administrative bodies, who are appointed for a certain term. In other words, the composition of this court is usually formed of current or retired judges, as well as other persons (Section 18, paragraph 2 of Section 19 of the 1987 Act; 2002). The decision of the Lok Adalat is mandatory for the parties and there is no appeal, since it is deemed that the parties themselves had determined the conditions for the dispute settlement (paragraph 2, Section 21 of the 1987 Act; 2002). The above advantages of the functioning and consideration of cases in the Lok Adalat proceedings have made this mechanism highly employable among the population of India.

According to a prominent comparativist as David (2002), the Chinese people are not interested in the norms that are contained in the laws, they do not go to court and regulate interpersonal relations as their sense suggests, following rather agreement and harmony than the law. This harmony is easy to restore because the Chinese have been brought up in such a way that they are looking for the causes of the conflict in their own mistakes, negligence, and oversight rather than in the evil will or inability of the rival. In an atmosphere where everyone is ready to admit their mistakes, people can easily be forced to make concessions and agree to mediation; fear of public opinion may make this consent coercive. The concept of out-of-court dispute settlement for the Chinese is a prerogative way of dispute resolution, in which preference is given to finding a way for a settlement agreement, while application of law is considered a major failure (David and Jauffret-Spinosi, 2002). This is one of the reasons why the state pays great attention to the development of alternative dispute resolution methods, the use of which has a long cultural tradition. The Chinese legislation admits the use of such 

arbitration (1995); 3) mediation in the arbitration trial (Kaufmann-Kohler and Fan, 2008).

In South Africa, the procedure for out-of-court dispute settlement is carried out through: 1) arbitration, 2) conciliation, 3) mediation, which are provided as an alternative way to dispute resolution in many legislative acts governing civil-commercial and public law relations. There is no legislative definition of the term "conciliation" in South Africa, but a number of legal acts directly indicate the possibility of referring to this mechanism for resolving disputes between the interested parties (for example, Labor Relations Act No. 66 of 1995). The use of conciliation procedures in the consideration of commercial, labor and other disputes meets the objectives of justice, which include promoting the establishment and development of business partnerships between contractors, employees and employers, etc.

The Commission for Conciliation, Mediation and Arbitration, hereinafter - CCMA and Commission) is one of the mechanisms designed to achieve this goal. In the Guidelines for Respondents (The South African Labour Guide, 2000), which were developed by the Commission on the basis of the aforementioned Labor Relations Act 1995, and supplemented with the CCMA Rules (2000), the following advantages of the conciliation procedure are emphasized: voluntary participation of each party in all its stages, cost effectiveness, confidentiality and the ability to resolve the dispute in less time. All decisions reached between the parties in the course of conciliation procedures must be recorded in writing, and failure to comply with this peremptory norm entails the deprivation of the right of the parties to refer to the results of the compromise achieved in future.

\section{Conclusion}

Study and analysis of the legislation of the BRICS countries make it possible to talk about a fairly developed system of bodies that resolve disputes in a quasi-judicial order. India and South Africa are common law countries on this issue; therefore, the practice of one of these countries - the United States - is quite indicative. Similar proceeding (quasi-judicial procedure) is defined in paragraph 551 of the US Code (2020): "adjudication" means agency process for the formulation of an order (clause 7). And the "order" means the whole or a part of a final disposition, whether affirmative, negative, injunctive, or declaratory in form, of an agency in a matter other than rule making but including licensing (clause 6). The above formula shows that administrative proceedings are judicial in nature. At the same time, it is known that operation of some institutions is not limited to consideration of applications (claims) of individuals, while others have a single function - consideration of disputes.

What can be said about the idea of ADR development, practical implementation thereof, the benefits to the parties, the state and others? Undoubtedly, the courts of major contemporary states are loaded, overstretched, with regard to the current time, when justice has become even 
make it possible to bring cases to court via the Internet, etc. Under these conditions, they seek to redistribute this burden based on the provisions of the Constitution and law. Entering into force and existing laws provide for a wide variety of out-of-court dispute settlement methods, which have both their advantages and their disadvantages. Some institutional constraints appear during their development (lack of premises that are separated from the courts; lack of qualified mediators, intermediaries, etc.); there are also psychological constraints in the form of the inability of society and the population to adopt a different procedure for protecting their rights, ignorance of the basics of ADR, etc. Nevertheless, in our opinion, this process cannot be stopped, it will only gain momentum, and the rest (judges, the public, etc.) only need to get used to and find ways to interact as successfully as possible in the new changing conditions.

\section{Acknowledgements}

The publication has been prepared with the support of the "RUDN University Program 5-100".

\section{References}

Act No. 2 of 1974, 25th January, 1974. Retrieved from: http://www.oecd.org/site/adboecdanticorruptioninitiative/46814340.pdf

Act No. 45 of 1860, 6th October, 1860. Retrieved from: http://www.oecd.org/site/adboecdanticorruptioninitiative/46814358.pdf

Alternative Dispute Resolution of South African Law Commission (1997). Project No. 94 of July 15, 1997. Department of Justice and Constitutional Development of Republic of South Africa. Retrieved from: http://www.justice.gov.za/salrc/ipapers/ip08_prj94_1997.pdf

Ampeire, P. (2017). ADR in South Africa: A Brief Overview. Retrieved from: https://www.imimediation.org/2017/12/09/adr-south-africa-brief-overview/

Arbitration and Conciliation (1996). Act No. 26 of 1996. Retrieved from: http://legislative.gov.in/sites/default/files/A1996-26.pdf

Arbitration Law of the People's Republic of China (1994). Adopted at the Ninth Meeting of the Standing Committee of the Eighth National People's Congress on August 31, 1994 and promulgated by Order No.31 of the President of the People's Republic of China on $\begin{array}{llll}\text { August } & \text { 31, } & \text { Retrieved } & \text { from: }\end{array}$ https://www.wipo.int/edocs/lexdocs/laws/en/cn/cn138en.pdf

Arbitration Procedure Code of the RF dated 24.07.2002 No. 95-FZ (revised as of 31.12.2014, amended as of 21.03.2014). Russian Official Gazette, No. 30, Article 3012. Retrieved from: http://www.apcode.ru/doc.php?docid=37800

Arbitration Procedure Code of the RF dated March 5, 1992. No. 2447-1. Russian Official Gazette. Retrieved from: http://www.apcode.ru/doc.php?docid=00373 
Baistrocchi, E. (2012). Tax Disputes under Institutional Instability: Theory and Implications.

The Modern Law Review, 75(4), 547-577. DOI: 10.1111/j.1468-2230.2012.00914.x

Bannikov, R.Yu. (2012). Pre-trial procedure of dispute settlement. Moscow: Infotropic.

Barnard-Naude, J. (2012). Adjudication, interpretation and dispute resolution. In Humby T, and Kotze L.J., A.A. du Plessis (Eds). Introduction to Law and Legal Skills in South Africa. 1st Edition. Cape Town: Oxford University Press. Retrieved from: https://www.researchgate.net/publication/296596926_Introduction_to_law_and_legal_ skills_in_South_Africa

Belikova, K. (2012). Legal Framework of the Competition Environment within BRICS Countries: Novels in the Brazil Legislation. Vestnik Mezhdunarodnykh OrganizatsiiInternational Organizations Research Journal, 7(4), 239-247. Retrieved from: http://iorj.hse.ru/2012--4/70752367.html

Belikova, K.M. (2015). National Features and Prospects for the Unification of Private Law of the BRICS Countries: Textbook in 2 vol. Moscow: RUDN University Press. Retrieved from: http://nkibrics.ru/system/asset_publications/

Belikova, K.M. (2016). General approaches to dominant market position, prohibition of abuse of market power, and market structure control within the BRICS countries. BRICS Law Journal, 3(1), 7-33. https://doi.org/10.21684/2412-2343-2016-3-1-7-33

Burtovaya, E.V. (2002). Conflictology. Moscow: YUNITI. Retrieved from: https://uchebnikonline.com/soderzhanie/textbook_71.html

Chandra, T. (2019). Non-Litigation Process Land Dispute Settlement for Legal Certainty. Substantive Justice International Journal of Law, 2(2), 177-194. ISSN 2599-0462. doi: http://dx.doi.org/10.33096/substantivejustice.v2i2.49.

Chernik, I.D. (2012). Pre-trial settlement of tax disputes. Moscow: Nalogovy Vestnik Retrieved from: https://base.garant.ru/57858626/

Chumikov, A.N. (1997). Negotiating: strategy, communication, facilitation, mediation. Moscow: Lomonosov Moscow State University Press. Retrieved from: https://search.rsl.ru/ru/record/01000567992

Civil Code of the Russian Federation. Russian Official Gazette, 05.12.1994, N 32, Article 3301.

Civil Procedure Code (CPC) dated 09.04.1991 (revised as of 28.10.2007). Retrieved from: http://chinalawinfo.ru/procedural_law/law_civil_procedure

Civil Procedure Code of the RF dated 14.11.2002 No. 138-FZ (revised as of 31.12.2014). Russian Official Gazette, 18.11.2002, No. 46, Article 4532.

Culture and Negotiations: Russian Style. Retrieved from: https://embahs.skolkovo.ru/en/embahs/blog/culture-and-negotiations-the-russian-style/ 
Davis, B.D., Netzley, M. (2001). Alternative Dispute Resolution: A Business (and) Communication Strategy. Business Communication Quarterly, 64(4), 83-89. https://doi.org/10.1177/108056990106400409

Dhavan, R. (2013). A workload fix for the apex court. Mail Today. India Today. Retrieved from: http://indiatoday.intoday.in/story/supreme-court-lawyers-judges-arrears-highcourts-human-rights-cases-workload-reform/1/257312.html

Dutta, R. (2015). Mediation in India. Building on Progress. Retrieved from: https://www.ibanet.org/Document/Default.aspx\%3FDocumentUid\%3DB705AE330AF0-4DA2-9C93-7421D28D2767+\&cd=17\&hl=en\&ct=clnk\&gl=ru

Engelmann, F. (2015). Sentidos políticos da Reforma do Judiciário no Brasil [Political senses of Judicial reform in Brazil]. Direito E Práxis, 6(3), 395-412. DOI: 10.12957/dep.2015.17304

Prokhorov, A. (Ed.) (1978). Great Soviet Encyclopedia (1969-1978). Russia: Sovetskaya Publishing House. Retrieved from: http://slovari.yandex.ru/

Guidelines for Respondents. Retrieved from: http://www.labourguide.co.za/ccmainformation/guidelines-for-respondents-316

Internet Conference of the Chairman of the Supreme Arbitration Court of the Russian Federation V.F. Yakovlev "Pre-trial dispute settlement and dispute settlement at an early stage of legal proceedings". February 19, 2004. Retrieved from: http://www.garweb.ru/conf/vas/20040219/

Kaufmann-Kohler, G., Fan, K. (2008). Integrating Mediation into Arbitration: Why it Works in China. Journal of International Arbitration, 25(4), 479-492.

Khudoykina, T.V. (2001). Legal conflictology: from the starting points of the theory to the practice of resolving and preventing a legal conflict. Saransk: Ogarev Mordovia State University Press. Retrieved from: https://search.rsl.ru/ru/record/01000747103

Kozyrin, A.N. (1996). Administrative law of foreign countries. Textbook. Moscow: SPARK. Retrieved from: http://be5.biz/pravo/a005/index.html

Labour Relations Act No. 66 of 1995. (Act No. 66 of 1995). Government Gazette, No. 16861, 13 December of 1995. Retrieved from: https://www.gov.za/documents/labour-relationsact

Supreme Court of India (2018). Mediation Training Manual of India. Delhi, India: Supreme Court of India. Retrieved from: https://mediate.com/articles/Mediation-in-India.cfm Nosyreva, E.I. (2007). Conciliation procedures and international commercial arbitration. In Komarov, A.S. (Eds.). International Commercial Arbitration: Current Problems and Solutions: Collection of Articles devoted to the 75th Anniversary of the International Commercial Arbitration Court at the Chamber of Commerce of the Russian Federation. Moscow: Statute. 
Part One of the Tax Code of the Russian Federation of July 31, 1998 No. 146-FZ. Russian Official Gazette of August 3, 1998 No. 31 Article 3824; Part Two of the Tax Code of the Russian Federation of August 5, 2000 No. 117-FZ. Russian Official Gazette, No. 32 Article 3340.

People's Mediation Law adopted at the 16-th session of the Standing Commission of the 11ep National People's Congress dated August 28, 2010 (Decree of the CPC Chairman No.34). Retrieved from: https://asia-business.ru/law/law3/agent/

Poole, Ch.K. (2011). The development of ADR and neutrality in Brazil. Jams ADR Blog. Retrieved from: http://jamsadrblog.com/2011/09/30/the-development-of-adr-andneutrality-in-brazil/

Presidential address to the Federal Assembly of the Russian Federation. (2012). Retrieved from: http://www.kremlin.ru/events/president/news/17118

Putin approved the mandatory claims procedure for resolving arbitration disputes. 02.03.2016.

Retrieved from: http://rapsinews.ru/arbitration/20160302/275509221.html

Putin cancelled in part pre-trial dispute settlement in ADR. July 3, 2017. Retrieved from: https://pravo.ru/news/view/142339/

Relyea, G., Bhatt, N.J. (2009). Comparing Mediation and Lok Adalat: Toward An Integrated Approach To Dispute Resolution In India. Retrieved from: https://mediate.com/articles/relyeaGbhattN1.cfm?nl=215

Riskin L., Westbrook, J. (1987). Dispute resolution and lawyers. West Publishing Co. Retrieved from:

https://books.google.ru/books/about/Dispute_Resolution_and_Lawyers.html?id=4oLP ZVZNHYUC\&hl=en\&output=html_text\&redir_esc=y

Rules Regulating the Practice and Procedure for Resolving Disputes through Conciliation and at Arbitration Proceedings. Regulation Gazette no. 6633, Government Notice R.245 of 31 March 2000 (commonly known as "the CCMA Rules"). Retrieved from: http://www.labourguide.co.za/ccma-information/guidelines-for-respondents-316

Sharma, B. (2009). Lok Adalats as most popular ADR mode in India: with special reference to H.P. Retrieved from: http://www.adrcentre.in/images/pdfs/LOK_ADALATS_IN_H.P.$\%$ 20Final.pdf

Somov, L. (2004). Pre-trial procedure of dispute settlement. Financial Gazette, 9-11. Retrieved from: http://www.for-expert.ru/articles/fin_gazeta-9-2004.shtml

Stepan, P. (n.d.). Alternative Dispute Resolution Methods. Retrieved from: http://law.edu.ru/doc/document.asp?docID=1129449

Strategy for the development of the financial market of the Russian Federation until 2020. Approved by Government Order of the Russian Federation dated December 29, 2008. 
No. 2043. RG-Business, No. 687 of January 27, 2009, No. 688 of February 3, 2009.

Retrieved from: http://www.rg.ru/2009/02/03/finansy-strategia-dok.html

The Code of Civil Procedure, 1908 (Act No. 5 of 1908). Retrieved from: http://www.vakilno1.com/bareacts/civil-procedure/civil-procedure-code-1908.html

The Legal Service Authorities Act (No. 39 of 1987, as amended 2002). Retrieved from: http://cgslsa.gov.in/Acts/Act.pdf

Tikhomirov, Yu.A. (2001). Law of Conflict: Educational Scientific and Practical Guide. Moscow: NORMA. Retrieved from: http://lawlibrary.ru/izdanie37004.html

Young, J.H., Zhu, L. (2012). Overview of China's New Labor Dispute Mediation and Arbitration Law.

Retrieved

from: http://www.dwt.com/advisories/Overview_of_Chinas_New_Labor_Dispute_Mediatio n_and_Arbitration_Law_01_29_2008/(accessed on 10.05.2020)

Zelentsov, A.B. (1997). Administrative Justice. Textbook. Moscow: RUDN University Press. Retrieved from: https://search.rsl.ru/ru/record/01001776715 